MAReK A. MOTYKA

ORCID 0000-0001-6967-0035

Uniwersytet Rzeszowski

\title{
UWARUNKOWANIA LIBERALIZACJI STANOWISK WOBEC NARKOTYKÓW ORAZ ICH ZAŻYWANIA ZIDENTYFIKOWANE W ŚRODOWISKU SZKOLNYM - DANE Z BADAŃ
}

\begin{abstract}
Aвstract. Motyka Marek A., Uwarunkowania liberalizacji stanowisk wobec narkotyków oraz ich zażywania zidentyfikowane w środowisku szkolnym - dane z badań [Reasons for the Liberalization of Attitudes Towards Drugs and their Use Identified in the School Environment - Research Data]. Studia Edukacyjne nr 55, 2019, Poznań 2019, pp. 223-243. Adam Mickiewicz University Press. ISSN 1233-6688.
\end{abstract} DOI: $10.14746 /$ se.2019.55.13

Over the past few decades, researchers of drug addiction have drawn attention to the unprecedented dynamics in the positions on drugs and a growing number of people who admit to the use of such substances for hedonistic and recreational purposes. An intensification of drug addiction led to the identification of a large number of drug-related problems which occur on individual, social and global levels. The last decade has abounded in seemingly uncontrollable, numerous events linked mainly to the spread of "legal highs". These events included: legal trade in those products in Poland, two waves of numerous deaths associated with their use, the extremely unscrupulous distribution of "legal highs" through websites, and particularly the liberalisation of attitudes towards those new designer drugs. The considerable importance in creating positions in favour of drug use should also be attributed to the popularity of marijuana, increasingly gaining a status of a recreational drug.

This paper discusses the current reasons why the youth begin to use drugs as identified in the school environment. The research focused on obtaining reliable data allowing to diagnose the phenomenon of drug use by the young people in Podkarpacie Province and to determine factors contributing to drug initiation among this segment of population. In the quantitative research, the empirical data were collected through a specially designed questionnaire from a random sample of young people from 27 secondary schools in Podkarpacie Province $(n=2237)$. Within the sample, 712 students $(31 \%)$ admitted to using drugs. The most important educational factors for promoting psychoactive substances are low involvement in education and frequent school absences. Drugs are more commonly used by older students. The research material presented in this article can be successfully used by practitioners in the field, including sociologists, educators and psychologists, and by institutions active in social prevention. It can also form the starting point for further explorations of this important social phenomenon.

Key words: youth, school environment, alcohol, drugs 


\section{Wprowadzenie}

Środowisko szkolne wraz ze środowiskiem rodzinnym i rówieśniczym stanowią dla adolescentów zasadnicze obszary funkcjonowania oraz wszelkiej aktywności. Na podstawie wzorców zaobserwowanych w tych środowiskach, młodzież kształtuje swoje postawy, internalizuje normy, uczy się relacji interpersonalnych, staje się członkiem bądź autsajderem danej społeczności. Środowiska te pełnią istotną rolę w procesie dorastania: szkoła jest miejscem nabywania wiedzy, a zarazem umiejętności niezbędnych do interakcji społecznych ${ }^{1}$; środowisko rówieśnicze - oparte na regułach zachowań obserwowanych u osób istotnych dla jednostki oraz ich przejmowanie bądź odrzucanie - sprzyja definiowaniu siebie ${ }^{2}$; środowisko rodzinne winno stanowić płaszczyznę stabilizacyjną wobec rozbieżności, które mogą się pojawiać u dziecka w wyniku obserwacji przeciwstawnych stanowisk wobec powszechnie przyjętych norm (uczciwości, szacunku, poszanowania własności wspólnej, zażywania środków odurzających itp.). Rodzina pełni funkcje kontrolne, korygujące i wspierające, niezbędne dla prawidłowego samopoczucia i rozwoju jej członków.

Środowisko szkolne jest miejscem doświadczania stanów emocjonalnych zarówno przyjemnych i oczekiwanych, jak również nieprzyjemnych, a przy tym przewlekłych. Przyczynę ambiwalentnych doznań stanowią zarówno kontakty z osobami bliskimi, z którymi jednostka odczuwa potrzebę obcowania - ze względu na towarzyszące tym relacjom przyjemne uczucia, jak i niemiłe napięcia związane z przebywaniem w zróżnicowanej grupie rówieśników o nierzadko skrajnych priorytetach, stylach życia, sposobach działania. Wysoce stresogenna jest ponadto świadomość ciągłej oceny postępów $\mathrm{w}$ nauce podczas całego procesu edukacji.

Zetknięcie się ze środkami o psychoaktywnym potencjale wydaje się zjawiskiem obserwowanym częściej w środowiskach rówieśniczym i rodzinnym $^{3}$, niż w placówkach edukacyjnych. Środowisko szkolne jednak, z uwagi na sporą ilość czasu poświęcaną przez adolescentów wszelkim aktywno-

\footnotetext{
${ }^{1}$ E. Miturska, Poczucie koherencji oraz inne czynniki chroniace przed uzależnieniem a przekonania i doświadczenia w używaniu narkotyków, [w:] Badania problemów społecznych, 2, red. J. Kwaśniewski, Warszawa 2006, s. 55-56.

${ }^{2}$ E. Kulawska, Uwarunkowania i konsekwencje odrzucenia dziecka w wieku szkolnym przez grupe rówieśnicza, Seminare. Poszukiwania naukowe, 2013, 33, s. 194.

3 A.A. Rawa, Rodzinne uwarunkowania narkomanii wśród młodzieży, Annales Universitatis Mariae Curie-Skłodowska. Sectio J, Paedagogia-Psychologia, 2002, 15, s. 10-11; P. Ulman, Spoteczne i rodzinne uwarunkowania uzależnień u dzieci i młodzieży, Fides et Ratio, 2011, 4(8), s. 80-85; E. Kopeć, Samotność w rodzinie źródtem patologii wśród dzieci i młodzieży, Pedagogika Katolicka, 2013, 1(12), s. 44-59; M. Motyka, Uwarunkowania narkomanii młodzieży: zagrożenia w środowisku rodzinnym i rówieśniczym, s. 38-55.
} 
ściom edukacyjnym, może posłużyć do obserwacji uwarunkowań związanych z otoczeniem szkoły, ich wpływu na stanowiska wobec środków psychoaktywnych oraz podejmowanie decyzji o używaniu tychże.

\section{Cel badań}

Zasadniczym celem prezentowanych badań empirycznych, zrealizowanych wśród młodzieży szkół ponadgimnazjalnych województwa podkarpackiego, było ustalenie społeczno-kulturowych uwarunkowań sięgania po środki psychoaktywne. Eksploracji poddano uwarunkowania rodzinne, kulturowe, środowiskowe i szkolne, przyjrzano się związkom zachodzącym między korzystaniem z treści kultury masowej a stosunkiem do narkotyków $i$ ich używaniem, czynnikom demograficznym oraz ekonomicznym ${ }^{4}$.

W niniejszej pracy przedstawiono relacje zidentyfikowane między uwarunkowaniami związanymi ze środowiskiem szkolnym a stanowiskami wobec środków psychoaktywnych oraz ich zażywaniem. W przeprowadzonym pomiarze podjęto się ustalenia związków między profilem szkoły, do której uczęszcza młodzież i rocznikiem uczniów a zażywaniem narkotyków oraz między wskazywanym samopoczuciem w klasie a deklaracjami używania tych środków. Sprawdzono również wpływ podawanego zaangażowania w proces edukacji na zażywanie narkotyków. Za wskaźniki określające owo zaangażowanie przyjęto status uczniowski (najczęściej otrzymywane oceny), udział w dodatkowych zajęciach szkolnych (koła naukowe, kursy językowe itp.), dalsze plany edukacyjne oraz stosunek do zajęć szkolnych (wagarowanie bądź regularne uczestnictwo).

\section{Materiał i metody}

Zaprezentowane dane pochodzą z badań empirycznych zrealizowanych w roku szkolnym 2015-2016 wśród losowo dobranej próby uczniów szkół ponadgimnazjalnych województwa podkarpackiego. W celu uzyskania reprezentatywnych danych zastosowano warstwowo-losowy dobór próby: teren badań podzielono na trzy warstwy (warstwa I - szkoły z Rzeszowa jako stolicy województwa; warstwa II - szkoły z miast powyżej 20 tys. mieszkańców; warstwa III - szkoły z miast do 20 tys. mieszkańców i szkoły wiejskie), następnie wylosowano miejscowości, a w dalszej kolejności szkoły z wylosowa-

${ }^{4}$ M. Motyka, Społeczno-kulturowe uwarunkowania zjawiska narkomanii (socjologiczne studium młodzieży Podkarpacia), rozprawa doktorska, http://repozytorium.ur.edu.pl/handle/item/2546 [data dostępu: 20.06.2017]. 
nych wsi i miast (za wyjątkiem warstwy I, w której wylosowano wyłącznie placówki edukacyjne). W każdej warstwie wylosowano po pięć szkół o profilu ogólnokształcącym i cztery szkoły techniczne. Następnie w placówkach tych wybierano po jednym oddziale z każdego rocznika. Dobór klas do próby badawczej ustalono na podstawie możliwości organizacyjnych wybranych szkól; zazwyczaj badania przeprowadzano podczas godzin wychowawczych, zajęć sportowych lub lekcji religii. Do zbierania danych użyto autorski kwestionariusz ankiety. Przy aprobacie Wojewódzkiego Kuratora Oświaty - oraz za przyzwoleniem dyrektorów szkół - anonimowe badania zostały przeprowadzone osobiście przez autora projektu, bez obecności nauczyciela, co zwiększało komfort uczniów, a zarazem mogło sprzyjać podawaniu przez nich wiarygodnych danych. Przed realizacją badań właściwych w trzech szkołach (po jednej z każdej warstwy) przeprowadzono pilotaż w celu weryfikacji narzędzia badawczego.

Łącznie w pomiarze uczestniczyło ponad 2500 uczniów ze 103 oddziałów klasowych z 27 szkół województwa. Po selekcji zgromadzonego materiału empirycznego do analiz statystycznych zakwalifikowano 2273 poprawnie wypełnione kwestionariusze. Dane zakodowano w programie kalkulacyjnym IBM SPSS Statistic 20, a następnie poddano analizie z wykorzystaniem narzędzi statystycznych tego programu. Istotność związków między zmiennymi określono z zastosowaniem testu Chi-kwadrat, natomiast siłę zidentyfikowanych związków zmierzono korzystając ze współczynników Phi, V-Cramera i Gamma. Za istotne pod względem statystycznym przyjęto wartości na poziomie istotności $\mathrm{p} \leq 0,001$.

\section{Wyniki}

Badaniami empirycznymi objęto młodzież uczęszczającą do dziennych szkół ponadgimnazjalnych: liceów ogólnokształcących i szkół technicznych. W grupie badawczej młodzież licealna stanowiła 53\% (1203 uczniów), natomiast uczniowie techników 47\% (1070osób). Wśród licealistów przeważającą grupą były dziewczęta (64\%), zaś wśród uczniów techników - chłopcy (57\%). W zestawieniu ogólnym w pomiarze uczestniczyło 1045 chłopców (46\%) i 1228 dziewcząt (54\%).

Wśród badanej młodzieży niemal jedną trzecią stanowili uczniowie klas pierwszych (32\%), którzy w każdej badanej szkole byli grupą najbardziej liczną. Uczniowie drugich i trzecich klas mieli po $29 \%$ reprezentantów, natomiast najmniej liczną grupą byli uczniowie klas czwartych, którzy w próbie badawczej stanowili jedynie 10\%. Niski odsetek czwartoklasistów wynikał między innymi z doboru próby badawczej, w której część respondentów podejmowa- 
ła naukę w liceach ogólnokształcących (brak czwartej klasy), jak również był rezultatem mniej liczebnych oddziałów klasowych w tych rocznikach.

W objętej pomiarem próbie badawczej swoje kontakty z narkotykami (kiedykolwiek w życiu) potwierdziło 712 uczniów stanowiących niemal trzecią część badanych (31\%).

Zebrany materiał empiryczny wskazuje, że wśród młodzieży województwa podkarpackiego zażywanie środków psychoaktywnych nie jest zjawiskiem marginalnym; kontakty z marihuaną potwierdził średnio co trzeci ankietowany - 675 osób (30\%), a do zażywania innych narkotyków przyznało się 202 uczniów (9\%); palenie tytoniu potwierdziło 511 uczniów (23\%), a spożywanie alkoholu - 1468 (65\%). Biorąc pod uwagę płeć respondentów, chłopcy częściej potwierdzali kontakty z alkoholem (chłopcy: 69\%; dziewczęta: 61\%) i narkotykami (chłopcy: 38\%; dziewczęta: 26\%). Wskazania palenia papierosów w obu grupach były wyrównane.

W niniejszej pracy marihuana i inne narkotyki traktowane są oddzielnie ze względu na takie różnicowanie tych środków przez samych respondentów. W trakcie pilotażu narzędzia badawczego znaczna część uczniów oponowała przed kwalifikacją marihuany do grupy narkotyków, dlatego zadecydowano o wprowadzeniu podziału. W kategorii „inne narkotyki” młodzież zgłaszała najczęściej zażywanie amfetaminy, "dopalaczy”, kokainy, LSD i ecstasy. W kilku zestawieniach niniejszej pracy podano kategorię „narkotyki ogółem", która określa ogólną liczbę osób sięgających po narkotyki.

\section{Profil szkoły a zażywanie narkotyków}

Pierwszą kwestią podjętą przy eksploracji środowiska szkolnego respondentów było ustalenie związku między profilem szkoły i zażywaniem narkotyków.

W zebranych od uczniów, zgromadzonych kwestionariuszach swoje doświadczenia z narkotykami częściej potwierdzali uczniowie szkół technicznych, spośród których 36\% (380 osób) wskazało ich używanie, w porównaniu $\mathrm{z}$ licealistami, $\mathrm{w}$ grupie których kontakty z narkotykami potwierdziło $28 \%$ (332 osoby). Analiza danych empirycznych wykazała, że między profilem szkoły a zażywaniem narkotyków zachodzi związek istotny statystycznie: $\chi^{2}(1,2273)=16,497 ; p \leq 0,001 ; \varphi=0,085 ;$ młodzież ucząca się w szkołach technicznych częściej potwierdza zażywanie narkotyków niż młodzież kształcąca się w liceach. Wartość współczynnika Phi, określająca siłę związku zachodzącego między tymi zmiennymi, wskazuje jednak, że zależności te nie są duże. Można więc przyjąć, że wskazania zażywania narkotyków pośród uczących się w szkołach o profilu ogólnym i technicznym są zbliżone. Na podstawie 
danych uzyskanych $w$ trakcie analizy empirycznej należy jednak przyjąć, że po narkotyki nieco częściej sięgają uczniowie szkół technicznych niż licealiści.

Wyrównywanie się wskazań zażywania w szkołach o różnych profilach nauczania potwierdza podobną popularność środków odurzających w obu typach szkół. Możliwe, że nieco wyższe dane wśród uczniów szkół technicznych są rezultatem częstszego przebywania poza szkołą (praktyki zawodowe), posiadaniem do dyspozycji pieniędzy pozyskiwanych $z$ dodatkowych zajęć pozalekcyjnych (drobne zlecenia związane z przyuczanym zawodem, prace "na czarno"), bądź stanowią pochodną innych czynników, których nie rozpoznano w trakcie tego pomiaru. Supozycje te mogą być podstawą bardziej szczegółowych eksploracji wśród młodzieży szkół ponadgimnazjalnych, natomiast dane zgromadzone w omawianych badaniach - ze względu na nieduże różnice w wyselekcjonowanych grupach i słabą siłę związku - nie powinny być uznawane za kluczowe przyczyny narkomanii wśród młodzieży województwa podkarpackiego.

\section{Rocznik respondentów}

Jest to kolejna zmienna, którą zestawiono z uzyskanymi od respondentów wskazaniami zażywania narkotyków, ale również deklaracjami korzystania z pozostałych środków o działaniu psychoaktywnym: napojów energetyzujących, papierosów, alkoholu oraz marihuany.

W badaniu uczestniczyło 32\% uczniów pierwszych klas, po $29 \%$ - drugich i trzecich, oraz 10\% czwartoklasistów. Zgromadzone dane empiryczne potwierdzają, że wraz z wyższym rocznikiem respondentów rosną wskazania palenia papierosów: od co szóstego pierwszoklasisty (17\%) do jednego na trzech palących w najstarszej grupie (35\%); spożywania alkoholu: od $41 \%$ pierwszoklasistów do dziewięciu na dziesięciu najstarszych uczniów (92\%); palenia marihuany, do którego przyznaje się 18\% najmłodszych, natomiast w najwyższych rocznikach już niemal czterech na dziesięciu (39\%); jak i sięgania po inne narkotyki, do zażywania których przyznaje się 5\% uczniów pierwszych klas, w stosunku do których w grupie najstarszych respondentów odsetek ten wzrasta niemal trzykrotnie (14\%). Jedynie w przypadku spożywania napojów energetyzujących grupa respondentów potwierdzających ich używanie jest niższa $\mathrm{w}$ drugich i trzecich klasach (w pierwszej: 65\%, w drugiej: $61 \%$ i trzeciej: $60 \%$ ), co może być związane z zaspokajaniem subiektywnych potrzeb (odurzania się) silniejszymi środkami (alkoholem, marihuaną, innymi narkotykami). Wśród najstarszych respondentów siedmiu na dziesięciu $(70 \%)$ potwierdza spożywanie napojów energetyzujących, co w przypadku tej grupy może się wiązać z wyższą potrzebą stymulacji legal- 
nymi „wzmacniaczami” z konieczności większego zaangażowania w naukę (zakończenie edukacji na etapie szkoły ponadgimnazjalnej). W tabeli 1 przedstawiono szczegółowe wskazania używania tych środków w każdym z badanych roczników.

Tabela 1

Używanie środków psychoaktywnych w kategoriach wiekowych (rocznik)

\begin{tabular}{|c|c|c|c|c|c|c|}
\hline \multicolumn{2}{|c|}{ Rocznik } & $\begin{array}{c}\text { I } \\
\text { klasa }\end{array}$ & $\begin{array}{c}\text { II } \\
\text { klasa }\end{array}$ & $\begin{array}{c}\text { III } \\
\text { klasa }\end{array}$ & $\begin{array}{c}\text { IV } \\
\text { klasa }\end{array}$ & Statystyki \\
\hline \multirow{5}{*}{ 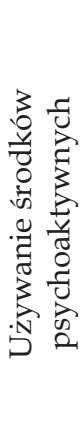 } & „energizery” & $65 \%$ & $63 \%$ & $59 \%$ & $71 \%$ & brak związku \\
\hline & papierosy & $17 \%$ & $21 \%$ & $26 \%$ & $35 \%$ & $\begin{array}{l}p \leq 0,001 ; \\
\text { V-Cramera = 0,125 }\end{array}$ \\
\hline & alkohol & $41 \%$ & $60 \%$ & $86 \%$ & $92 \%$ & $\begin{array}{l}\mathrm{p} \leq 0,001 \\
\text { Gamma }=0,488\end{array}$ \\
\hline & marihuana & $18 \%$ & $31 \%$ & $38 \%$ & $39 \%$ & $\begin{array}{l}p \leq 0,001 \\
\text { Gamma }=0,270\end{array}$ \\
\hline & $\begin{array}{l}\text { inne } \\
\text { narkotyki }\end{array}$ & $5 \%$ & $9 \%$ & $11 \%$ & $14 \%$ & $\begin{array}{l}p \leq 0,001 \\
\text { Gamma }=0,264\end{array}$ \\
\hline
\end{tabular}

Źródło: badania własne $(\mathrm{n}=2273)$.

Jak można zauważyć, wartość współczynnika Gamma jest najwyższa przy wskazaniach spożywania alkoholu, co potwierdza najsilniejszy związek pośród ustalonych między wyróżnionymi zmiennymi. W pozostałych kategoriach (z wyjątkiem zmiennej „napoje energetyzujące”), mimo wskazywanej niedużej siły związków, deklaracje palenia tytoniu, marihuany i zażywania innych narkotyków są istotne statystycznie i wyraźnie wzrastają z każdym kolejnym rocznikiem.

W analizie materiału empirycznego podjęto się również ustalenia odpowiedzi na pytanie: jaki jest związek między wiekiem (rocznikiem) respondentów i zażywaniem narkotyków (ogółem). Do kategorii „zażywający” przypisano wszystkich uczniów potwierdzających, że mieli kiedykolwiek w życiu kontakt z marihuaną, jak i tych, którzy potwierdzali zażywanie innych narkotyków, bowiem w badaniu nie wszyscy palacze marihuany mieli kontakt z innymi narkotykami, jak również nie każdy zażywający inne narkotyki potwierdzał używanie pochodnych konopi. Po zestawieniu danych można zauważyć wyraźne różnice między wskazaniami zażywania uzyskanymi od pierwszoklasistów (wśród których średnio co piąty (20\%) potwierdził kontakty z narkotykami) a pozostałymi rocznikami, w których wskazania zażywania wyraźnie wzrastają. Wśród uczniów drugich klas, co trzeci potwierdził 
inicjację narkotykową (34\%), natomiast wśród trzecio- i czwartoklasistów kontakty z narkotykami wskazało średnio czterech na dziesięciu uczniów (39\% i 38\%). Analiza materiału empirycznego potwierdziła, że między zmiennymi występują różnice istotne statystycznie: $\chi^{2}(3,2273)=71,687 ; p \leq 0,001$; $\mathrm{V}$-Cramera $=0,178$. Dane te pozwalają przyjąć, że im wyższy rocznik, tym częstsze wskazania zażywania narkotyków. Wartość współczynnika V-Cramera określa, że siła związku nie jest duża, jednak różnice we wskazaniach są wyraźnie zauważalne.

Zastanawiający wydaje się wysoki odsetek potwierdzających kontakty z narkotykami wśród najmłodszych badanych (20\%). W przypadku tej grupy nie powinno się jeszcze mówić o wpływie środowiska szkolnego, w jakim się znaleźli na zażywanie narkotyków, ponieważ badania zostały przeprowadzone w pierwszych miesiącach nowego roku szkolnego, co wydaje się zbyt krótkim czasem na uznawanie zażywania narkotyków jako doświadczenia nabytego w nowej szkole. Można zatem przypuszczać, że inicjacja narkotykowa wśród respondentów z tej grupy miała już miejsce wcześniej, być może na etapie gimnazjum bądź podczas wakacji poprzedzających podjęcie nauki w szkole ponadgimnazjalnej. $\mathrm{W}$ innych badaniach przeprowadzonych przez autora artykułu wśród gimnazjalistów uzyskano wyniki potwierdzające wzrost zażywania środków psychoaktywnych w tej grupie uczniów wraz z podawanym rocznikiem, przy czym najwyższe wskazania spożywania alkoholu i palenia marihuany uzyskano wśród najstarszych gimnazjalistów ${ }^{5}$. Część tych uczniów prawdopodobnie kontynuuje edukację, przenosząc doświadczenia nabyte w poprzednim etapie kształcenia na płaszczyznę szkoły ponadgimnazjalnej.

\section{Relacje interpersonalne $\mathrm{w}$ klasie}

\section{Samopoczucie w klasie}

Prawidłowe relacje między uczniami mogą stanowić o dobrym samopoczuciu uczestników szkolnych interakcji, natomiast poczucie odrzucenia przez rówieśników - jak wskazuje Agnieszka Pisarska - może generować podejmowanie zachowań ryzykownych ${ }^{6}$. W celu ustalenia, czy subiektywne odczucia młodzieży wynikające z ich relacji z innymi uczniami w klasie mogą wpływać na sięganie po narkotyki, sformułowano dwa kolejne problemy ba-

${ }^{5}$ M. Motyka, Zachowania ryzykowne przemyskich gimnazjalistów, Problemy Higieny i Epidemiologii, 2016, 97(3), s. 244.

${ }^{6}$ A. Pisarska, Czynniki ryzyka i czynniki chroniace zwiazane z ryzykownymi i problemowymi zachowaniami młodzieży: kilka wskazówek, [w:] Ryzyko używania narkotyków przez młodzież. Poradnik dla pracowników szkót i placówek oświatowych oraz rodziców, red. D. Macander, Ośrodek Rozwoju Edukacji, Warszawa 2014, s. 36-37. 
dawcze. Pierwszy: jaki jest związek między samopoczuciem w klasie wskazywanym przez respondenta i zażywaniem narkotyków?

W kwestionariuszu ankiety zadano uczniom pytanie: jak się czują w swojej klasie. Do określenia nastroju zaproponowano pięć odpowiedzi skalujących ich subiektywne odczucia. $W$ trakcie analizy materiału empirycznego ustalono, że 39\% uczniów czuje się w klasie „bardzo dobrze”, 45\% wskazało odpowiedź "dobrze”, złe samopoczucie zaznaczyło nieco ponad $2 \%$ badanych i niespełna $1 \%$ podało odpowiedź "bardzo źle”, natomiast $13 \%$ nie potrafiło zająć stanowiska. W związku z niedużym odsetkiem badanych przy odpowiedziach wskazujących "złe" i „bardzo złe” samopoczucie na potrzeby analiz zrekodowano uzyskane dane, łącząc je w jedną kategorię, następnie analogicznie zrekodowano wskazania potwierdzające "dobre" i „bardzo dobre" samopoczucie. W ten sposób uzyskano trzy typy odpowiedzi, w których „pozytywny” nastrój w klasie zgłaszało 84\% uczniów, 3\% określało go „negatywnie", a 13\% stanowiły osoby, które nie potrafiły podać jednoznacznej odpowiedzi („,ani dobrze, ani źle”). Dane te zestawiono z podanymi wskazaniami zażywania narkotyków.

W grupie respondentów zaznaczających odpowiedzi sklasyfikowane jako "pozytywne" - 30\% potwierdziło zażywanie narkotyków, wśród mających trudności z jednoznacznym wskazaniem samopoczucia (,ani dobrze, ani źle") zażywanie narkotyków potwierdził podobny odsetek (33\%), natomiast spośród uczniów, którzy zaznaczyli odpowiedzi potwierdzające "negatywne" doznania w klasie, do zażywania narkotyków przyznała się połowa respondentów (50\%). Podawane przez niektórych uczniów przyczyny gorszych relacji z rówieśnikami, to między innymi „brak akceptacji i tolerancji dla inności”, „brak poczucia wspólnoty”, "nadmierna rywalizacja o stopnie", ,"egoizm”, ,"brak zrozumienia”, ,zawiść", „podziały między uczniami”, "trudności z asymilacją po zmianie szkoły".

Analiza zgromadzonego materiału empirycznego nie wykazała jednak związku istotnego pod względem statystycznym między wskazywanym samopoczuciem a zażywaniem narkotyków.

\section{Poczucie akceptacji bądź odrzucenia rówieśniczego}

Drugi problem badawczy dotyczył ustalenia roli relacji interpersonalnych w sięganiu po narkotyki. Celem analizy danych empirycznych było ustalenie związku między subiektywnym poczuciem bycia nieakceptowanym i zażywaniem narkotyków. Jak zauważyła Ilona Malorny, akceptacja ze strony kolegów, przyjaciól, znajomych z klasy liczy się dla adolescentów najbardziej, a środowisko rówieśnicze jest dla nich istotnym punktem odniesienia. Lęk przed brakiem akceptacji ze strony grupy, z którą się oni utożsamiają, stanowił jedną z przyczyn sięgania po narkotyki, ustalonych przez autorkę podczas eksploracji śro- 
dowiska osób zażywających te środki ${ }^{7}$. Dlatego, w prezentowanych badaniach podjęto decyzję o sprawdzeniu związku między tymi dwiema zmiennymi.

W odpowiedziach na zamieszczone w kwestionariuszu pytanie: Czy uważasz siebie za osobẹ akceptowana przez rówieśników? 82\% uczniów szkół objętych niniejszym pomiarem podało odpowiedź potwierdzającą, $2 \%$ zaprzeczyło, a 16\% nie potrafiło się wypowiedzieć. Dane te wskazują, że jedynie niewielka grupa uczniów uważa się za osoby nieakceptowane, natomiast zdecydowana większość nie doświadcza takiego dyskomfortu. Odpowiedzi te po zestawieniu z deklaracjami zażywania narkotyków wskazują, że w grupie osób dotkniętych poczuciem odrzucenia przez rówieśników z klasy zażywanie narkotyków potwierdził najwyższy odsetek (44\%), natomiast w pozostałych dwóch grupach do zażywania przyznał się średnio jeden na trzech badanych. Analiza statystyczna nie wykazała jednak związku między tymi zmiennymi $(p=0,096)$. Między uczniami uważającymi się za osoby akceptowane a tymi, którzy tego nie doświadczają, nie stwierdzono istotnych statystycznie różnic we wskazaniach zażywania narkotyków.

\section{Zaangażowanie w edukację}

Jedną ze zmiennych używanych podczas ustalania uwarunkowań zjawiska narkomanii jest status uczniowski, określany przez uczniów głównie na podstawie ocen otrzymywanych za naukę. Według Doroty Macander, zainteresowanie nauką w szkole jest jednym z najważniejszych czynników chroniących przed podejmowaniem zachowań ryzykownych (m.in. przed zażywaniem narkotyków $)^{8}$. Badacze potwierdzają, że po środki odurzające częściej sięgają uczniowie otrzymujący niższe stopnie, a rzadziej ci, którzy otrzymują wyższe ${ }^{9}$, chociaż zidentyfikowano również dane wskazujące na brak różnic między tymi zmiennymi ${ }^{10}$.

W prezentowanych badaniach podjęto się ustalenia związku między zażywaniem narkotyków a czterema zmiennymi wskazującymi większą bądź mniejszą aktywność edukacyjną: wspomnianymi stopniami za naukę, uczestnictwem $\mathrm{w}$ dodatkowych zajęciach pozalekcyjnych, deklaracjami dalszego kształcenia oraz częstotliwością celowych absencji w szkole.

${ }^{7}$ I. Malorny, Ryzyko uzależnienia młodzieży szkolnej od narkotyków, Katowice 2016, s. 124.

8 D. Macander, Profilaktyki uzależnień w szkole - e-poradnik, Ośrodek Rozwoju Edukacji, Warszawa, s. 11, https://www.ore.edu.pl/materialy-do-pobrania [data dostępu: 15.12.2017].

${ }_{9}$ A. Malczewski, Epidemiologia używania narkotyków przez młodziė̇, [w:] Ryzyko używania narkotyków przez młodzież. Poradnik, s. 17.

${ }_{10}$ A. Kolbowska, Konsumpcja substancji psychoaktywnych przez młodzież szkolna, Serwis Informacyjny - Narkomania, 2009, 1(45), s. 36. 


\section{Status uczniowski}

Spośród uczestników badań 18\% zaznaczyło, że są uczniami szóstkowo-piątkowymi, 43\% uznało się za "czwórkowych”, natomiast 39\% badanych wskazało, że otrzymują w szkole trójki i niższe stopnie. Dane te zestawiono z podanymi deklaracjami kontaktów z wybranymi środkami psychoaktywnymi.

Wśród uczniów otrzymujących najwyższe oceny palenie tytoniu zaznaczyło 12\%, pośród „czwórkowych" - 16\%, natomiast pośród "trójkowych” do palenia papierosów przyznało się 35\% badanych ( $\mathrm{p} \leq 0,001$; V-Cramera $=0,241$. Analogicznie, wśród najlepszych uczniów kontakty z alkoholem potwierdziło 51\%, pośród „czwórkowych” - 60\%, zaś pośród otrzymujących najniższe stopnie spożywanie alkoholu zaznaczyło trzy czwarte (76\%) respondentów ( $\mathrm{p} \leq 0,001 ; \mathrm{V}$-Cramera = 0,224). Do zażywania narkotyków przyznał się średnio co szósty (16\%) z grupy otrzymujących najlepsze stopnie, średnio co czwarty uczeń (27\%) z grupy „czwórkowych”, natomiast w grupie wskazującej otrzymywanie najniższych ocen zażywanie tych środków potwierdziło zdecydowanie najwięcej badanych (43\%). Analiza statystyczna potwierdziła występowanie związku między wskazywanym statusem uczniowskim a zażywaniem narkotyków: $X^{2}(2,2273)=114,125 ; \mathrm{p} \leq 0,001 ; \mathrm{V}$-Cramera = 0,224. Powyższe dane potwierdzają, że uczniowie osiągający wyższe oceny istotnie rzadziej sięgają po papierosy, alkohol i narkotyki niż uczniowie otrzymujący niższe stopnie.

\section{Udział w dodatkowych zajęciach pozalekcyjnych}

Spośród osób biorących udział w badaniu ponad połowa (55\%) zaprzeczyła angażowaniu się w dodatkowe zajęcia pozalekcyjne, natomiast pozostali uczniowie (45\%) potwierdzili podejmowanie takich aktywności. Najczęściej wskazywane zajęcia to korepetycje, szkolne i pozaszkolne koła naukowe, fakultety przedmaturalne, zajęcia z języków obcych, kursy komputerowe i zajęcia z informatyki, nauka tańca oraz zajęcia sportowe. Uzyskane odpowiedzi na temat uczestnictwa w dodatkowych zajęciach zestawiono z deklaracjami zażywania narkotyków. Jednak między respondentami uczestniczącymi w dodatkowych zajęciach a nie uczestniczącymi w nich, nie stwierdzono istotnych statystycznie różnic we wskazaniach zażywania narkotyków: średnio co trzeci badany z jednej i drugiej grupy potwierdził, że ma za sobą narkotykową inicjację. Analiza statystyczna nie wykazała związku między uczestnictwem w zajęciach pozalekcyjnych a zażywaniem tych środków; można więc przypuszczać, że wśród badanej młodzieży podejmowanie dodatkowych aktywności edukacyjnych nie stanowiło potencjału chroniącego przed sięganiem po narkotyki. 


\section{Plany dalszej nauki}

Celem kolejnego pytania badawczego było ustalenie związku między deklarowaną kontynuacją edukacji i zażywaniem narkotyków. Jedno z pytań kwestionariusza posłużyło ustaleniu planów w zakresie dalszego kształcenia respondentów. Odpowiedź potwierdzającą takie ambicje zaznaczyło $63 \%$ badanych, co czwarty (26\%) nie był w stanie określić swoich zamiarów, natomiast $11 \%$ stwierdziło, że planuje zakończyć naukę na obecnym etapie. $\mathrm{W}$ ramach analizy danych ustalono $w$ tych grupach występowanie dysproporcji w deklaracjach zażywania narkotyków. Wśród respondentów potwierdzających gotowość dalszej edukacji do ich przyjmowania przyznał się średnio co czwarty badany (26\%), w grupie uczniów nie potrafiących przedstawić swego stanowiska zażywanie tych środków potwierdziło 39\%, natomiast najwyższe wskazania kontaktów z narkotykami zidentyfikowano wśród uczniów nie zamierzających się dalej uczyć (45\%). Analiza statystyczna potwierdziła, że zachodzi związek między zestawionymi zmiennymi: $\chi^{2}(2,2273)=56,113$; $\mathrm{p} \leq 0,001$; V-Cramera $=0,157$. Uczniowie planujący kontynuację nauki rzadziej sięgają po środki o narkotycznym potencjale.

Niewykluczone, że aspiracje edukacyjne stanowią dla adolescentów czynnik chroniący przed zażywaniem narkotyków, a powstrzymywanie się od zażywania tych środków, w obawie przed wystąpieniem ewentualnych deficytów intelektualnych, może stanowić skuteczną barierę odgradzającą uczniów od narkotykowych inicjacji. Świadomość potencjalnych strat, na przykład dyskwalifikacja z wymarzonego kierunku studiów (osoby z „kartoteką" policyjną za posiadanie narkotyków nie mogą ubiegać się o przyjęcie na kierunki prawnicze), może mieć walory chroniące.

Niska wartość współczynnika V-Cramera nie świadczy o występowaniu silnych zależności, jednak na podstawie danych uzyskanych podczas analizy statystycznej należy przyjąć, że uczniowie deklarujący kontynuację swojej edukacji rzadziej sięgają po narkotyki niż uczniowie bez takich aspiracji.

\section{Zamierzone absencje szkolne}

Celem ostatniego pytania badawczego związanego ze środowiskiem szkolnym było ustalenie związku między wagarowaniem a liberalizacją stosunku do narkotyków i ich zażywaniem. W kwestionariuszu na pytanie dotyczące celowych absencji, respondenci mieli możliwość wskazać jedną z trzech proponowanych odpowiedzi, w których do „częstego" opuszczania zajęć szkolnych przyznało się 7\% uczniów, co drugi badany (51\%) potwierdzil, że robi to sporadycznie, natomiast $42 \%$ respondentów zaprzeczyło wagarowaniu. Wskazania te zestawiono $\mathrm{z}$ danymi potwierdzającymi kontakty z narkotykami.

Przeprowadzona analiza materiału empirycznego wykazała, że w grupie uczniów zaprzeczających chodzeniu na wagary występuje najniższy odse- 
tek wskazań zażywania narkotyków (15\%), wśród potwierdzających niezbyt częste celowe opuszczanie zajęć szkolnych po narkotyki sięgało czterech na dziesięciu uczniów (39\%), natomiast wśród wskazujących „częste" wagarowanie aktywności takie potwierdziło ponad trzy czwarte badanych $(78 \%)$. Analiza statystyczna podanych odpowiedzi potwierdziła, że między zmiennymi zachodzi związek istotny statystycznie: $\chi^{2}(2,2273)=305,154 ; p \leq 0,001$; $\mathrm{V}$-Cramera $=0,366$. Dane te pozwalają przyjąć, że młodzież wagarująca częściej sięga po narkotyki niż młodzież niewagarująca. Wartość współczynnika V-Cramera uprawnia do stwierdzenia, że pośród badanych przyczyn zażywania narkotyków w środowisku szkolnym wagarowanie należy uznać za zmienną najbardziej sprzyjającą sięganiu po te środki.

Zażywanie narkotyków przez wagarującą młodzież może mieć różną etiologię. Uczniowie opuszczający zajęcia szkolne mogą to robić z powodu problemów rodzinnych, konfliktów z rówieśnikami, pod wpływem innych osób, z lęku przed otrzymaniem gorszej oceny w przypadku nieprzygotowania do zajęć; z pewnością częściej w związku z doświadczaniem silnych nieprzyjemnych stanów emocjonalnych niż przyjemnych. Skorzystanie z propozycji zażycia narkotyku w takich okolicznościach jest znacznie łatwiejsze niż wówczas, kiedy jednostka nie doświadcza wewnętrznych kryzysów. Ponadto, podjęcie decyzji o przyjęciu narkotyków może być znacznie łatwiejsze w przypadku jednostki decydującej się na celowe opuszczenie szkoły, bowiem naruszanie jednej normy (obowiązek uczestnictwa w zajęciach) może sprzyjać podejmowaniu decyzji o łamaniu innych norm (podejmowanie zachowań społecznie nieakceptowanych).

Inicjacja narkotykowa może nastąpić również pod wpływem alkoholu spożywanego podczas wagarów ${ }^{11}$. Dane dotyczące spożywania napojów alkoholowych przez młodzież uczestniczącą w badaniu zestawione $\mathrm{z}$ odpowiedziami odnoszącymi się do wagarowania potwierdziły, że wśród osób wagarujących, bez względu na częstotliwość, zgłaszane są najwyższe odsetki kontaktów z alkoholem (77\% pośród wagarujących rzadko i 92\% wśród wagarujących często). Analiza danych empirycznych potwierdziła, że we wskazaniach spożywania alkoholu występują różnice między młodzieżą, która nie wagaruje a opuszczającą zajęcia szkolne: $\chi^{2}(2,2273)=302,067 ; p \leq 0,001$; $\mathrm{V}$-Cramera $=0,365$. Spożywanie alkoholu podczas szkolnych absencji może zatem sprzyjać sięganiu po narkotyki.

Ponadto, wśród uczniów potwierdzających zamierzone absencje w szkole zaobserwowano bardziej liberalne postawy wobec narkotyków. W prezento-

${ }^{11}$ K.L. Henry, T.P. Thornberry, Truancy and Escalation of Substance Use During Adolescence, Journal of Studies on Alcohol and Drugs, 2010, 71(1), s. 115-124; R. Dembo i in., Impact of Brief Intervention Services on Drug Using Truant Youth Arrest Charges over Time, Journal of Child and Adolescent Substance Abuse, 2014, 23(6), s. 375-388. 
wanym pomiarze postawy te zostały określone dwiema zmiennymi: 1) postrzeganiem narkotyków jako środków bezpiecznych oraz 2) stanowiskiem wobec legalizacji marihuany. Korzystając z sugestii Kazimiery Wódz, dla uniknięcia skojarzeń związanych z przyjętym w praktyce badawczej rozumieniem pojęcia "postawy”, jak i mogącymi się pojawiać zarzutami o nieuzasadnione posługiwanie się tym pojęciem ${ }^{12}$, bardziej poprawne wydało się zastąpienie terminu "postawy" mianem "stosunku” do narkotyków. Stosunek ten - w ramach analiz zgromadzonych danych empirycznych - został zidentyfikowany przez ustalenie związków między wpływem wybranych zmiennych (w tym wypadku wagarowania) na wspomniane powyżej postrzeganie narkotyków jako środków bezpiecznych, jak również przyjmowaniu stanowiska za legalizacją marihuany.

Zestawienie danych wykazało, że uczniowie nie wagarujący potwierdzają najniższe wskazania zarówno wobec postrzegania narkotyków jako środków bezpiecznych (13\%), jak i wobec legalizacji marihuany $(28 \%)$. Wraz z rosnącą częstotliwością absencji szkolnych stanowiska te ulegają zróżnicowaniu; wśród uczniów potwierdzających sporadyczne wagarowanie co czwarty uważa, że narkotyki są bezpieczne, zaś wśród zgłaszających częste absencje jest to już niemal co drugi badany. Analogicznie, wśród wskazujących rzadkie opuszczanie zajęć za legalizacją marihuany opowiada się połowa respondentów, natomiast $\mathrm{w}$ grupie uczniów często wagarujących za prawnym przyzwoleniem korzystania z tego narkotyku opowiedziało się siedmiu na dziesięciu badanych (tab. 2).

Tabela 2

Częstotliwość wagarowania/stanowisko wobec środków psychoaktywnych

\begin{tabular}{|c|c|c|c|c|c|}
\hline \multicolumn{2}{|c|}{$\begin{array}{l}\text { Częstotliwość } \\
\text { wagarowania }\end{array}$} & $\begin{array}{c}\text { Nie } \\
\text { wagaruję }\end{array}$ & $\begin{array}{c}\text { Wagaruje } \\
\text { rzadko }\end{array}$ & $\begin{array}{c}\text { Wagaruję } \\
\text { często }\end{array}$ & Statystyki \\
\hline \multirow{2}{*}{ 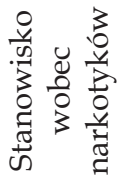 } & są bezpieczne & $13 \%$ & $24 \%$ & $45 \%$ & V-Cramera $=0,205$ \\
\hline & $\begin{array}{l}\text { za legalizacją } \\
\text { marihuany }\end{array}$ & $28 \%$ & $49 \%$ & $70 \%$ & V-Cramera $=0,254$ \\
\hline
\end{tabular}

Źródło: badania własne (n= 2273).

Analiza materiału empirycznego wykazała, że między wskazaniami dotyczącymi wagarowania a postrzeganiem narkotyków jako środki bezpieczne zachodzi związek istotny statystycznie: $\chi^{2}(2,2273)=94,642 ; \mathrm{p} \leq 0,001$;

${ }^{12}$ K. Wódz, Pomoc społeczna w świadomości mieszkańców miasta. Analizy teoretyczne i empiryczne badania społeczności wielkomiejskiej, Katowice 1985, s. 62. 
V-Cramera $=0,205$, podobnie jak między wskazaną częstotliwością absencji szkolnej a liberalnym stanowiskiem wobec legalizacji marihuany $\chi^{2}(2,2273)$ $=145,206 ; \mathrm{p} \leq 0,001 ; \mathrm{V}$-Cramera $=0,254$.

Dane te sugerują, że stanowiska wobec narkotyków mogą ulegać zniekształceniu wskutek spotykania się w trakcie wagarów z pronarkotykowymi aktywnościami obserwowanymi u osób z grona rówieśniczego, podejmowania pod wpływem znajomych narkotykowych inicjacji, a następnie liberalizacji stosunku do narkotyków, będącej konsekwencją osobistych doświadczeń adolescentów z tymi środkami.

Podsumowując czynniki sprzyjające zażywaniu narkotyków związane ze środowiskiem szkolnym, należy uznać, że z wymienionych uwarunkowań wagarowanie stanowi zmienną wykazującą najsilniejszy związek ze zmianą stosunku do narkotyków, a w rezultacie z ich używaniem.

\section{Dyskusja}

Przeglądając wyniki pomiarów przeprowadzanych w ostatniej dekadzie w tej grupie wiekowej, można zauważyć zarówno analogie, jak i pewne rozbieżności. W badaniach zrealizowanych w 2009 roku wśród licealistów $(n=1100)$ i ich rodziców z powiatu kaliskiego, do kontaktów z alkoholem przyznało się $53 \%$ ogółu badanych. Pod względem płci przeważali chłopcy $(64 \%)$, jednak spośród objętych pomiarem dziewcząt niemal połowa $(47 \%)$ również zaznaczała jego spożywanie. Alkoholem najpopularniejszym wśród uczniów było piwo (88\% wskazań), jednakże mocniejsze trunki również cieszyły się dużym zainteresowaniem badanych ${ }^{13}$. W pomiarze przeprowadzonym przez Katarzynę Śmigielską wśród uczniów szkół gimnazjalnych i ponadgimnazjalnych powiatu pleszewskiego $(n=1053)$, regularne palenie tytoniu potwierdziło 20\% młodzieży w wieku 14-19 lat. Ponad połowa badanych przynajmniej raz $\mathrm{w}$ życiu paliła papierosa; $\mathrm{w}$ grupie palaczy dominowali chłopcy, natomiast wzrost wskazań palenia odnotowywano wraz z wiekiem respondentów. Mimo świadomości szkód związanych z korzystaniem z tytoniu niemal jedna piąta $\mathrm{z}$ tej grupy potwierdzała, że są palaczami ${ }^{14}$. W tych samych badaniach kontakty z alkoholem (kiedykolwiek w życiu) potwierdziło ośmiu na dziesięciu badanych $(82 \%)$, przy czym różnice między chłopcami a dziewczętami były zbliżone (80\% dziewcząt i $84 \%$ chłopców). Niemal trzy

${ }^{13}$ P. Wojtyła-Buciora i in., Rozpowszechnienie konsumpcji alkoholu w opinii uczniów szkót licealnych $i$ ich rodziców, Hygeia Public Health, 2012, 47(4), s. 500.

${ }^{14}$ K. Śmigielska, Rozpowszechnienie używania środków psychoaktywnych wśród młodzieży szkót gimnazjalnych i ponadgimnazjalnych. Część I. Tytoń, Problemy Higieny i Epidemiologii, 2015, 96(3), s. 624. 
czwarte uczniów było świadomych szkód związanych z używaniem alkoho$l u^{15}$. Jak można zauważyć, wiedza ta - zarówno o konsekwencjach palenia tytoniu jak i spożywania alkoholu - nie stanowi czynników chroniących przed podejmowaniem tego typu aktywności.

W badaniach przeprowadzonych na próbie młodzieży pierwszych i ostatnich klas szkół ponadgimnazjalnych w województwie mazowieckim $(\mathrm{n}=3108)$, palenie papierosów potwierdziło niemal 28\% uczniów, spożywanie alkoholu $66 \%$, a prawie $11 \%$ wskazało zażywanie narkotyków. W tej ostatniej grupie niemal wszyscy potwierdzali palenie marihuany, za wyjątkiem sześciu osób, którzy wskazali, że sięgali po amfetaminę. Profil szkoły i klasa nie stanowiły o różnicach w sięganiu po środki psychoaktywne ${ }^{16}$.

Wczesna inicjacja alkoholowa lub narkotykowa może generować powstanie bardziej złożonych problemów w przyszłości. Dane potwierdzające wczesne kontakty z narkotykami zostały zaobserwowane między innymi przez Jacka Szczepkowskiego w grupie osób leczących się w ośrodku dla uzależnionych od narkotyków $(\mathrm{n}=210)$, pośród których najwyższe wskazania inicjacji alkoholowej określały ten okres między 11 a 15 rokiem życia, natomiast wiek pierwszych kontaktów z narkotykami oscylował między 12 a 16 rokiem życia ${ }^{17}$.

W innych badaniach zrealizowanych w środowisku uczniów szkół ponadgimnazjalnych można się spotkać z różnymi wskazaniami zażywania środków odurzających. $W$ pomiarze przeprowadzonym pośród licealistów z Zamościa $(\mathrm{n}=174)$, kontakty z narkotykami potwierdził co piąty badany $(19 \%)^{18}$, natomiast w badaniach zrealizowanych wśród uczniów technikum w Ostrowcu Świętokrzyskim (n = 75), do zażywania tych środków przyznało się $44 \%$ respondentów. Dane te jednak nie można uznać za reprezentatywne ze względu na nielosowy dobór próby ${ }^{19}$.

Porównując dane zgromadzone od podkarpackich adolescentów z wynikami badań zrealizowanych pośród polskich adolescentów w 2015 roku w ramach projektu European School Survey Project on Alcohol and Drug (ESPAD), dane uzyskane $\mathrm{w}$ niniejszym pomiarze są znacznie niższe od wyników zebranych od młodzieży II klas szkół ponadgimnazjalnych w populacji generalnej, gdzie palenie tytoniu potwierdziło niemal $40 \%$ badanych, spożywanie

${ }^{15}$ Tamże, s. 631.

${ }^{16}$ A. Saracen, Używanie tytoniu, alkoholi i substancji psychoaktywnych przez młodzież szkót ponadgimnazjalnych, Hygeia Public Health, 2010, 45(1), s. 68.

${ }_{17} \mathrm{~J}$. Szczepkowski, Resocjalizacja młodzieży uzależnionej oparta na potencjatach. W poszukiwaniu rozwiązań instytucjonalnych, Toruń 2016, s. 155.

${ }^{18}$ E. Kozłowska i in., Zjawisko stosowania substancji psychoaktywnych w wybranej grupie mtodzieży licealnej, Hygeia Public Health, 2016, 51(1), s. 103.

${ }_{19}$ H. Król i in., Samoocena stylu życia młodzieży w wieku 16-17 lat z powiatu ostrowieckiego w województwie świętokrzyskim, [w:] Zdrowie i Dobrostan 1/2014. Dobrostan i zespót, red. E. Dybińska, H. Duda, Lublin 2014, s. 64. 
alkoholu niemal 96\%, do palenia marihuany przyznało się 43\% uczniów, a do zażywania innych środków - zależnie od narkotyku - od 2 do nawet 17\% uczestników badań ${ }^{20}$. Należy jednak mieć na uwadze, że badania ESPAD są prowadzone na grupie znacznie bardziej zróżnicowanej (dodatkowo w skład próby badawczej wchodzą licea profilowane i zasadnicze szkoły zawodowe), dlatego dane z prezentowanego pomiaru - choćby ze względu na specyfikę doboru próby badawczej - mogą się od wyników ESPAD różnić.

Badacze zjawiska narkomanii w środowisku młodzieży wskazują, że wśród uczniów szkół ponadgimnazjalnych zażywanie narkotyków jest diagnozowane najczęściej w grupie wychowanków zasadniczych szkół zawodowych. Pod koniec 2013 roku Fundacja Centrum Badania Opinii Społecznej (CBOS) objęła polskich adolescentów badaniem: Konsumpcja substancji psychoaktywnych przez młodzież szkolnq - Młodzież 2013, w którym uczestniczyło 1360 uczniów ostatnich klas szkół ponadgimnazjalnych. Dane zebrane od młodzieży potwierdziły, że najwyższy odsetek wskazań zażywania odnotowano wśród uczniów „zawodówek” (26\%), natomiast niższy pośród młodzieży uczącej się w liceach (18\%) i szkołach technicznych $(12 \%)^{21}$. Badania zrealizowane pod koniec 2016 roku potwierdziły, że uczniowie zasadniczych szkół zawodowych - mimo spadku wskazań (aktualnie 21\%) - wciąż stanowią najwyższy odsetek użytkowników narkotyków wśród młodzieży placówek ponadgimnazjalnych. Pośród licealistów - w porównaniu z badaniami z 2013 roku - wskazania te obniżyły się o trzy punkty procentowe (obecnie $15 \%$ zażywających narkotyki w tej grupie $)^{22}$. Badania dotyczące zażywania "dopalaczy" również potwierdziły, że środki te są najbardziej popularne w grupie uczniów szkół zawodowych, natomiast od młodzieży uczącej się w ponadgimnazjalnych szkołach ogólnokształcących i szkołach o profilu technicznym zebrano zbliżone, jednak niższe wartości używania tych nowych narkotyków ${ }^{23}$.

Wskazania środków psychoaktywnych wśród uczniów liceów i techników z województwa podkarpackiego nie odbiegają znacząco od wskazań uzyskiwanych zarówno w lokalnych, jak i ogólnokrajowych pomiarach zjawiska. Jak zaznaczono wcześniej, po narkotyki częściej sięgają uczniowie techników, jednak na poziomie statystycznym różnice wskazań nie są znaczne.

${ }^{20}$ J. Sierosławski, Używanie alkoholu i narkotyków przez młodzież szkolną. Raport z ogólnopolskich badan ankietowych zrealizowanych w 2015 roku, Warszawa 2015, s. 13-38, http:/ / www.cinn. gov.pl/portal?id=166545 [data dostępu: 17.12.2017].

${ }^{21}$ A. Malczewski, Epidemiologia używania narkotyków przez młodzież, [w:] Ryzyko używania narkotyków przez młodzież. Poradnik, s. 17.

${ }_{22}$ A. Malczewski, Młodzież a substancje psychoaktywne, [w:] Młodzież 2016, CBOS/KBPN, Warszawa 2016, s. 118.

${ }^{23}$ A. Kolbowska, Dopalacze, Serwis Informacyjny - Narkomania, 2009, 1(45), s. 8-9. 
Biorąc pod uwagę status uczniowski i zażywanie narkotyków, w badaniach CBOS z lat 2013 i 2016, kontakt z tymi środkami częściej potwierdzali uczniowie otrzymujący najniższe stopnie (22\% w tej grupie). Wśród uczniów piątkowo-szóstkowych zażywanie narkotyków w 2016 roku zaznaczyło jedynie 13\% respondentów (12\% w 2013). Ponadto, uczniowie gorzej się uczący częściej zgłaszali sięganie po piwo i wódkę, niż badani otrzymujący najwyższe oceny ${ }^{24}$. Stosunek do nauki - odzwierciedlany ocenami szkolnymi - jest przez badaczy uznawany za czynnik chroniący przed sięganiem po środki odurzające; młodzież ucząca się lepiej niż przeciętnie znacznie rzadziej zgłasza kontakty z tego typu substancjami. W badaniach zrealizowanych w 2000 roku wśród uczniów szkół ponadgimnazjalnych warszawskiej dzielnicy Mokotów $(\mathrm{n}=1095)$ ustalono istotny pod względem statystycznym związek między podaną przez uczniów niską oceną wyników w nauce a wskazaniami palenia papierosów ${ }^{25}$. W badaniach zrealizowanych wśród warszawskich licealistów $(n=148)$ w połowie pierwszej dekady nowego milenium uczniowie z pozytywnym stosunkiem do szkoły i nauki znaczniej rzadziej wskazywali zażywanie środków z tej grupy niż uczniowie o pejoratywnych stanowiskach wobec edukacji ${ }^{26}$. W przywoływanym badaniu nie sprawdzano zależności między otrzymywanymi ocenami a zażywaniem narkotyków, jednak zmienna "stosunek do szkoły i nauki” może odzwierciedlać stopień zaangażowania w edukację, jak i oceny otrzymywane za owo zaangażowanie. Wyniki przywołanych badań korespondują z danymi uzyskanymi od młodzieży z województwa podkarpackiego.

Badania wpływu wagarowania na sięganie po narkotyki zostały przeprowadzone między innymi przez Kimberly L. Henry, która w przeprowadzonych pomiarach wzajemnych wpływów tych dwóch zmiennych stwierdziła występowanie między nimi istotnych zależności. Analizy danych zebranych od adolescentów potwierdziły, że wagary mogą być w tej grupie szczególnie silnym predyktorem używania środków psychoaktywnych. Badania wykazały ponadto, że nie tylko wagarowanie może sprzyjać sięganiu po narkotyki, ale również inicjacja narkotykowa, a w konsekwencji częstsze zażywanie narkotyków może być przyczyną celowych zamierzonych szkolnych absen$\mathrm{cji}^{27}$. Również $\mathrm{w}$ pomiarze przeprowadzonym przez zespół badaczy pod kierownictwem Richarda Dembo wagarująca młodzież została uznana za szczególnie zagrożony segment społeczny, w którym obserwowane są różnego rodzaju problemy edukacyjne, rodzinne oraz zachowania antyspołecz-

${ }^{24}$ A. Malczewski, Młodzież a substancje psychoaktywne, s. 218.

${ }^{25}$ K. Bobrowski, Poczucie koherencji oraz inne zasoby odpornościowe a używanie substancji psychoaktywnych przez młodzież, Alkoholizm i Narkomania, 2002, 5(2), s. 233-234.

${ }^{26}$ E. Miturska, Poczucie koherencji oraz inne czynniki chroniace przed uzależnieniem, s. 71-72.

${ }^{27}$ K.L. Henry, T.P. Thornberry, Truancy and Escalation of Substance Use During Adolescence, s. $115-124$. 
ne, między innymi zażywanie narkotyków ${ }^{28}$. Występowanie związku między wagarowaniem a używaniem środków psychoaktywnych (tytoniu, alkoholu, narkotyków) zostało także zidentyfikowane wśród polskiej młodzieży w badaniach przeprowadzonych w latach 2010-2014 przez Instytut Profilaktyki Zintegrowanej ( $n=13$ 960). Autorzy raportu nie potwierdzają, że między zmiennymi występuje zależność przyczynowo-skutkowa (że przyczyną zażywania narkotyków są wagary), jednak związki występujące między nimi zostały uznane jako silne ${ }^{29}$.

\section{Wnioski i zakończenie}

- Młodzież ucząca się w szkołach technicznych nieco częściej potwierdza zażywanie narkotyków niż młodzież kształcąca się w liceach.

- Im wyższy rocznik, tym częstsze wskazania zażywania narkotyków.

- Samopoczucie w klasie i subiektywne poczucie odrzucenia nie stanowią czynników decydujących o sięganiu po narkotyki.

- Uczniowie osiągający wyższe oceny za postępy w nauce istotnie rzadziej sięgają po papierosy, alkohol i narkotyki, niż uczniowie otrzymujący niższe stopnie.

- Uczniowie deklarujący kontynuację swojej edukacji rzadziej sięgają po narkotyki, niż uczniowie bez takich aspiracji.

- Młodzież wagarująca częściej potwierdza sięganie po różne środki psychoaktywne, niż młodzież zaprzeczająca celowym absencjom szkolnym.

Przedstawione badania mają swoje ograniczenia. Jak zaznaczono, eksploracji zostały poddane wypowiedzi młodzieży ze szkół ponadgimnazjalnych z wyłączeniem uczniów szkół zawodowych, szkół dla dorosłych, szkół artystycznych i innych placówek prowadzących edukację młodzieży w grupie wiekowej 16-20 lat. Poszerzenie badań o sondaże przeprowadzone w tych placówkach edukacyjnych z pewnością wzbogaciłoby wiedzę o postawach młodzieży wobec środków odurzających. Jak w wielu badaniach, tak i w prezentowanych uzyskane odpowiedzi stanowią podstawę do formułowania kolejnych problemów badawczych, na które należy poszukiwać odpowiedzi. Autor ma jednak nadzieję, że przedstawione wyniki mogą posłużyć podczas konstruowania strategii profilaktycznych pomagających skierować oddziaływania prewencyjne adekwatnie do potrzeb identyfikowanych w badanym środowisku.

Nie należy przyjmować, że u każdego ucznia potwierdzającego w niniejszych badaniach zażywanie środków odurzających wystąpi uzależnienie wy-

${ }^{28}$ R. Dembo i in., Impact of Brief Intervention Services, s. 375-388.

${ }^{29}$ Vademecum skutecznej profilaktyki problemów młodzieży, red. Sz. Grzelak, Warszawa 2015, s. $80-84$. 
magające podjęcia leczenia w specjalistycznych placówkach, jednak należy mieć na uwadze, że u części respondentów może ono wystąpić. Zidentyfikowanych związków zachodzących między wyróżnionymi zmiennymi nie powinno się bagatelizować.

Zaprezentowany materiał badawczy może z powodzeniem służyć socjologom, pedagogom, psychologom oraz instytucjom ukierunkowanym na profilaktykę społeczną. Może również stanowić bazę wyjściową do dalszego eksplorowania tego ważnego zjawiska społecznego zarówno w województwie podkarpackim, jak też $\mathrm{w}$ innych regionach kraju.

\section{BIBLIOGRAFIA}

Bobrowski K., Poczucie koherencji oraz inne zasoby odpornościowe a używanie substancji psychoaktywnych przez młodzież, Alkoholizm i Narkomania, 2002, 5(2).

Vademecum skutecznej profilaktyki problemów młodzieży. Przewodnik dla samorządowców i praktyków oparty na wynikach badań naukowych, red. Sz. Grzelak, Ośrodek Rozwoju Edukacji, Warszawa 2015.

Dembo R., Briones-Robinson R., Wareham J., Schmeidler J., Winters K.C., Barrett K., Ungaro R., Karas L.M., Belenko S., Impact of Brief Intervention Services on Drug Using Truant Youth Arrest Charges over Time, Journal of Child and Adolescent Substance Abuse, 2014, 23(6).

Henry K.L., Thornberry T.P., Truancy and Escalation of Substance Use During Adolescence, Journal of Studies on Alcohol and Drugs, 2010, 71(1).

Kolbowska A., Dopalacze, Serwis Informacyjny - Narkomania, 2009, 1(45).

Kolbowska A., Konsumpcja substancji psychoaktywnych przez młodzież szkolna, Serwis Informacyjny - Narkomania, 2009, 1(45).

Kopeć E., Samotność w rodzinie źródłem patologii wśród dzieci i młodzieży, Pedagogika Katolicka, 2013, 1(12).

Kozłowska E., Kowalczyk A., Marzec A., Kalinowski P., Zjawisko stosowania substancji psychoaktywnych w wybranej grupie młodzieży licealnej, Hygeia Public Health, 2016, 51(1).

Król H., Zboina B., Nowak-Starz G., Springer M., Biskup M., Strzelecka A., Słowik M., Samoocena stylu życia młodzieży w wieku 16-17 lat z powiatu ostrowieckiego w województwie świętokrzyskim, [w:] Zdrowie i Dobrostan 1/2014. Dobrostan i zespót, red. E. Dybińska, H. Duda, Wydawnictwo NeuroCentrum, Lublin 2014.

Kulawska E., Uwarunkowania i konsekwencje odrzucenia dziecka w wieku szkolnym przez grupe rówieśnicza, Seminare. Poszukiwania naukowe, 2013, 33.

Macander D., Profilaktyki uzależnień w szkole - e-poradnik, Ośrodek Rozwoju Edukacji, Warszawa, https:/ / www.ore.edu.pl/materialy-do-pobrania [data dostępu: 15.12.2017].

Malczewski A., Epidemiologia używania narkotyków przez młodzież, [w:] Ryzyko używania narkotyków przez młodzież. Poradnik dla pracowników szkót i placówek oświatowych oraz rodziców, red. D. Macander, Ośrodek Rozwoju Edukacji, Warszawa 2014.

Malczewski A., Młodzież a substancje psychoaktywne, [w:] Młodzież 2016, CBOS/KBPN, Warszawa 2016.

Malorny I., Ryzyko uzależnienia młodzieży szkolnej od narkotyków, Wydawnictwo UŚ, Katowice 2016. 
Miturska E., Poczucie koherencji oraz inne czynniki chroniace przed uzależnieniem a przekonania i doświadczenia w używaniu narkotyków, [w:] Badania problemów społecznych, 2, red. J. Kwaśniewski, Wydawnictwo IPSiR UW, Warszawa 2006.

Motyka M., Zachowania ryzykowne przemyskich gimnazjalistów, Problemy Higieny i Epidemiologii, 2016, 97(3).

Motyka M., Społeczno-kulturowe uwarunkowania zjawiska narkomanii (socjologiczne studium młodzieży Podkarpacia), rozprawa doktorska, http:/ / repozytorium.ur.edu.pl/handle/ item/2546 [data dostępu: 20.06.2017].

Motyka M., Uwarunkowania narkomanii młodzieży: zagrożenia w środowisku rodzinnym i rówieśniczym, [w:] Zagrożenia ładu społecznego oraz bezpieczeństwa narodowego. Wybrane aspekty, red. M. Gitling, I. Wojaczek, Wydawnictwo IS PWSW, Przemyśl 2017.

Pisarska A., Czynniki ryzyka i czynniki chroniace zwiazane z ryzykownymi i problemowymi zachowaniami młodzieży: kilka wskazówek, [w:] Ryzyko używania narkotyków przez młodzież. Poradnik dla pracowników szkót i placówek oświatowych oraz rodziców, red. D. Macander, Ośrodek Rozwoju Edukacji, Warszawa 2014.

Rawa A.A., Rodzinne uwarunkowania narkomanii wśród młodzieży, Annales Universitatis Mariae Curie-Skłodowska. Sectio J, Paedagogia-Psychologia, 2002, 15.

Saracen A., Używanie tytoniu, alkoholi i substancji psychoaktywnych przez młodzież szkót ponadgimnazjalnych, Hygeia Public Health, 2010, 45(1).

Sierosławski J., Używanie alkoholu i narkotyków przez młodzież szkolną. Raport z ogólnopolskich badań ankietowych zrealizowanych w 2015 roku, Warszawa 2015, http:/ / www.cinn.gov. $\mathrm{pl} /$ portal?id=166545 [data dostępu: 17.12.2017].

Szczepkowski J., Resocjalizacja młodzieży uzależnionej oparta na potencjałach. W poszukiwaniu rozwiazań instytucjonalnych, Wydawnictwo UMK, Torun 2016.

Śmigielska K., Rozpowszechnienie używania środków psychoaktywnych wśród młodzieży szkót gimnazjalnych i ponadgimnazjalnych. Część I. Tytoń, Problemy Higieny i Epidemiologii, 2015, 96(3).

Śmigielska K., Rozpowszechnienie używania środków psychoaktywnych wśród młodzieży szkót gimnazjalnych i ponadgimnazjalnych. Część II. Alkohol, Problemy Higieny i Epidemiologii, 2015, 96(3).

Ulman P., Społeczne i rodzinne uwarunkowania uzależnień u dzieci i młodziė̇y, Fides et Ratio, 2011, 4(8).

Wojtyła-Buciora P., Wojtyła A., Wojtyła C., Marcinkowski J.T., Rozpowszechnienie konsumpcji alkoholu w opinii uczniów szkót licealnych i ich rodziców, Hygeia Public Health, 2012, 47(4).

Wódz K., Pomoc społeczna w świadomości mieszkańców miasta. Analizy teoretyczne i empiryczne badania społeczności wielkomiejskiej, Wydawnictwo UŚ, Katowice 1985. 